
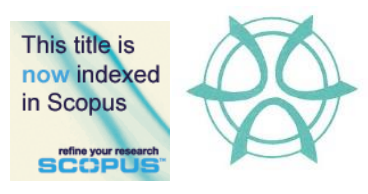

PLANNING MALAYSIA:

Journal of the Malaysian Institute of Planners

VOLUME 16 ISSUE 4 (2018), Page 199 - 207

\section{THE IMPORTANCE OF THE CONSERVATION/PRESERVATION WORKS: A CHALLENGE TOWARDS THE FUTURE OF NATIONAL HERITAGE}

\author{
Asyaari Muhamad ${ }^{1}$ \\ ${ }^{1}$ Institute of The Malay World and Civilization \\ UNIVERSITI KEBANGSAAN MALAYSIA
}

\begin{abstract}
This article discusses the importance of archaeology in the conservation and restoration works in Malaysia. Even though the development of archaeology in the nation is approximately 200 years, it is still considered a new subject. Even so, more than 50 research projects on the archaeological conservation of buildings and historical sites have been completed in this nation. Some of the archaeological conservation projects completed include Kota Kuala Kedah, the candi of Lembah Bujang, Fort Cornwallis, Suffolk House, High Courts, and Shop Houses of (Lebuh Acheh) in Pulau Pinang, Muzium Matang in Pasir Salak, Balai Budaya in Kuala Lumpur, Kota Lukut in Negeri Sembilan, Kota Melawati and Istana Bandar in Selangor, Bangunan Onn Jaafar in Johor and Fort Megarittha in Sarawak. These archaeological conservation projects had varying success. Successful in this context is when a site is uncovered with carefully preserved and restored archaeological finds and the reconstruction of certain structures whereas unsuccessful is when all the archaeological finds are disregarded or even destroyed. Therefore, this article attempts to uncover several factors about the importance of archaeological activities in the conservation or restoration of buildings and historical sites. Among that being suggested is that all historical buildings or sites that have to preserved and conserved should first be investigated archaeologically, all archaeological finds should be restored, and reconstructed in order to preserve the specific authenticity of the historical building or site, some funds should be set aside for these activities, and that it should be undertaken by an archaeologist who is experienced and trained in this field.
\end{abstract}

Keywords: archaeology, conservation, heritage 
Asyaari Muhamad

The Importance of The Conservation/Preservation Works: A Challenge Towards the Future of National Heritage

\section{INTRODUCTION}

The general public are aware of archaeology as a branch of social science, which studies the life of ancient society using a number of disciplines, starting with archaeological survey (primary and secondary), excavation, analysing and historical reconstruction. Scholars in this field since early times have painstakingly putting forward their thoughts, opinion and interpretations regarding archaeological findings. In other words, this field tries to venture into the life of ancient societies by their cultural legacy, namely artefacts and nonartefacts. To be precise, archaeologists try to look into their life from evidences left at ancient sites such as stones, bronze, iron, cast-offs, dwellings, ritual sites, grave sites, and so on.

Archaeological research is synonymous with how to preserve, conserve, restore and protecting the data acquired in whatever forms after the study has been carried out. This is important particularly to researchers in this field to think about the direction of the findings gathered from the studies undertaken. The direction refers to how to preserve and conserve the findings, how it is going to be managed by museum agencies, and how to present it to the general public in order to bring benefit to them (Renfrew \& Bahn, 1997; Harun, 2013). In other words, conservation aspect is very important in the field of archaeological research.

The archaeological aspect and conservation are interrelated. If emphasis is only on data collection without looking into management and conservation of the data, the archaeological research will be in vain. Archaeological conservation is crucial in identifying structure form, looking for evidence of original construction materials and artefacts such as metal, glass, bead, pottery and so on. In relation to the archaeological research, it must be carried out before restoration and conservation works on historical buildings and sites take place in order to plan for the real works of restoration and conservation (Harun, 2004).

Generally, conservation means skill in investigating techniques, maintenance and conservation of cultural heritage properties (Caple, 2000). Maintenance refers to the protection of monument from legacy and dispose, every existing traditional environment must be maintained and preserved from threat of destruction. Conservation is also a generic term used for any restoration works. It refers to conservation efforts using several techniques and technologies related to conservation discipline. Its concept is to preserve and expose the historical and aesthetical values of a monument (Kassim, 2006).

In reality, both archaeological and conservation fields play important roles in shaping, maintaining, and protecting national heritage. Therefore, the roles of authorities such as the Malaysian Ministry of Culture, Arts and Heritage, and agencies under it like the Museum Department and the Heritage Department, are very important in enhancing the value of national heritage. 
PLANNING MALAYSIA

Journal of the Malaysia Institute of Planners (2018)

Archaeological studies and conservation carried out in the country concentrated on all ages, starting with prehistoric, proto-historic and historic ages. But the level of studies on archaeology and conservation on prehistoric and proto-historic are quite different from historic age. During the prehistoric age, conservation works are focused on artefacts and non-artefacts such as potteries, human skeletons and flora. While, during the proto-historic age, conservation works concentrate on temple structure, artefacts and non-artefacts. During historic age, studies concentrate more on old houses which have historical value, historical buildings, mosques, fort and fortress. Nevertheless, archaeological conservation aspect has been given much attention mainly on the historic age. Hence, this essay will touch on archaeological studies carried out on old buildings, old mosques, old fort and fortress.

One vital aspect of conservation works, either of historical buildings or sites, is archaeological research. This includes taking into account building or site historical background, architectural and building survey (HABS), dilapidation, preparation of building and site plans, and so forth, so as to achieve the objective of a conservation project. This article will discuss several issues pertaining to archaeological research. It looks into issues in both fields in the last 20 years in Malaysia. Studies in both fields have been carried out extensively in the country either by researchers from local universities such as Universiti Kebangsaan Malaysia (UKM), Universiti Sains Malaysia (USM), Universiti Malaya (UM) and Mara Technology University (UiTM), government agencies such as Department of Museum of Malaysia or the private sector. However, the local universities mentioned above have made successful studies in both fields.

Among other things that will be discussed in this article are the historical background of conservation archaeological research in Malaysia, purpose and objective of research, and challenges and obstacles in conservation archaeology in Malaysia. This article concludes by suggesting several steps considered necessary to be implemented in achieving the real objective why archaeology is vital in the conservation of historical buildings and sites.

\section{HISTORY OF CONSERVATION ARCHAEOLOGICAL RESARCH IN MALAYSIA}

Starting from the founding of Malay Kingdoms such as Malacca Sultanate until the arrival of colonists like the Portuguese, the Dutch and the English, the history of the nation has left many significant evidences (Figure 1- Figure 3). A number of buildings, monuments and historical sites are still in existence, which can be traced back in many cities throughout the country. Conservation archaeological research activities in the country are pioneered by local experts since 1990's. Initially, the experts are involved in historical archaeology (Muhamad, 2005). In the early stage of conservation archaeological research development in the country, researchers always learn and exchange ideas with conservators in order 
Asyaari Muhamad

The Importance of The Conservation/Preservation Works: A Challenge Towards the Future of National Heritage

to fulfil the study objective and conservation goals. Trial and error have been the practice in research development during that stage.

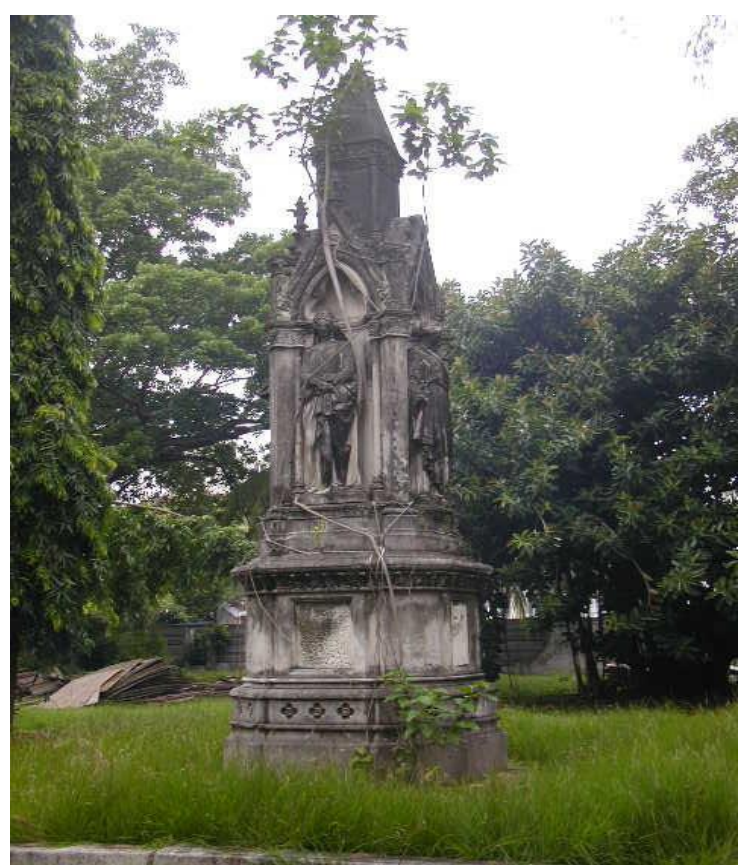

Figure 1: Sir James Richardson Logan memorial surrounded by old trees at High Court, almost 200 years old in Pulau Pinang Source: Fieldwork, 2005

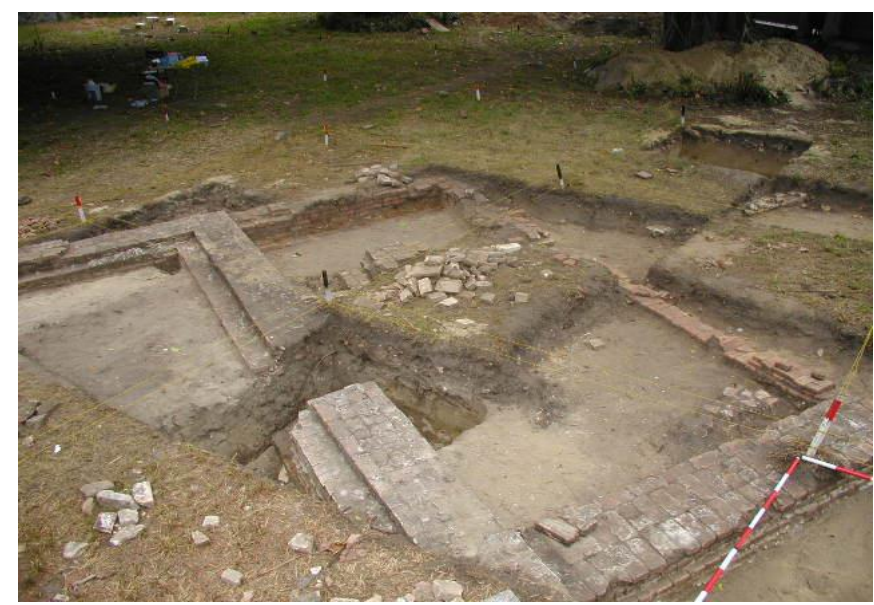

Figure 2: Excavation works which expose parts of original structure of the porch of the Supreme Court, Pulau Pinang

Source: Fieldwork, 2005 


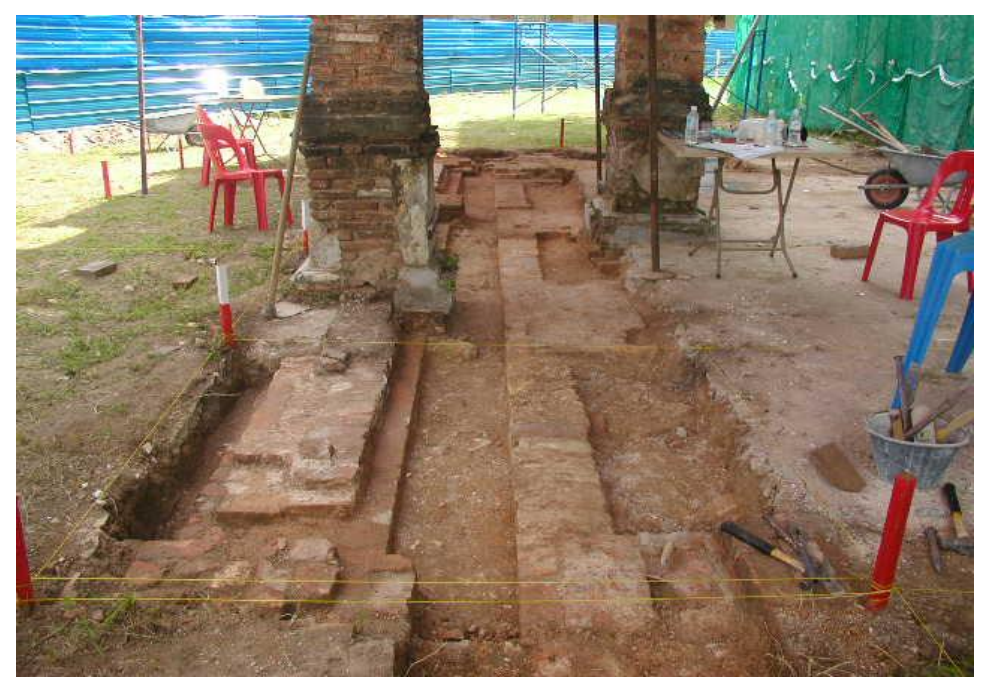

Figure 3: The southern porch structure of Suffolk House, which is exposed after archaeological excavation work has been carried out. Source: Fieldwork, 2005

\section{GOALS AND OBJECTIVE OF CONSERVATION ARCHAEOLOGICAL RESEARCH STUDIES}

The most important goals and objectives are to assist in resolving problem pertaining to building conservation. Goals and objectives of conservation archaeological research studies are usually based on Conservation Archaeology Method (CAM) and Rescue Archaeology Method (RAM) (Muhamad, 2007). Therefore, every archaeological studies that involves conservation work will focus on several aspects as follows:

i. CAM goals and objectives

- Suggest conservation aspects such as which structure should be retained by making conservation works so it will appear as it is in its original condition.

- Reconstruct exposed structures such as building's original floor, building structures, drain, roof are in line with the landscape of original building front yard.

- Observe how stratigraphy can be linked to events that take place in that area.

- Identify artefacts and non-artefacts distribution to be used as evidence and data of the area historical background.

- Protect and preserve the area carefully so that it can become a historical asset to benefit future generations. 
Asyaari Muhamad

The Importance of The Conservation/Preservation Works: A Challenge Towards the Future of National Heritage

ii. CAM goals and objectives

- Rescue all artefacts (ceramics, coins, weapons, ammunitions, metals, glasses, etc.)

- Rescue any building structure available (either transferred or rebuilt, such as gates, building foundations, floorings, drainage structures, staircase, etc.)

\section{CHALLENGES OF ARCHAEOLOGICAL RESEARCH IN CONSERVATION WORK}

\section{Confusion and Awareness}

Although many, including archaeologists and accredited conservators, acknowledge the importance of archaeological research in monuments and historical site conservation work, there are a handful of those responsible to carry out the tasks have neglected the archaeological conservation aspects in their conservation work. They assume the procedures are not important, it is costly, or they fear the finding from research will change the course of development that they have planned. Lack of experienced archaeologists in the field is also one of the obvious factors in creating confusion in conservation work. Less experienced archaeologists may not be able to resolve conservation problems on sites.

Findings from archaeological research are vital in determining future conservation works of any buildings or sites. However, it should be noted that archaeological research is not mandatory to be carried out on all building, monuments or historical sites, as long as the information collected from the site are adequate for the conservationist to carry out his/her duty. Moreover, small buildings without much damage may not need archaeological research to be carried out prior to conservation work. However, for huge historical building, with a lot of damage and disappearing landscape, archaeological research is a must in order to restore the condition of the original architecture of the building and the landscape of the site (Muhamad, 2005; Azman et al. 2011).

It is also unfortunate that when archaeological research was conducted, its results were ignored (Rahman, Ali, Wahab, \& Omar, (2016), leading to destruction of heritage buildings and sites. This is often due to clients overemphasising on development value as opposed to conservation or historical value. Some have conducted archaeological research superficially simply to fulfil their work contract requirements.

\section{Financial Implication}

This is considered to be one frequent challenge faced by Malaysian researchers and authorities in conservation archaeological research. Many consider it is costly to carry out any project which involves archaeological work in conservation. However, archaeological research often cost a lot less to conduct compared to the 
cost of engaging conservationist and consultant. The fees of conservationist and consultant are based on the value of the building, monument or site. At least 10\% to $15 \%$ of the total value are allocated to the consultant or conservationist. On the other hand, archaeological research usually will only cost less than 5\% of the total conservation cost of the building. Thus, it is misleading for many to consider archaeological research is expensive and hence to be omitted from conservation work (Caple, 2000; Harun, Ariffin, \& Abdullah, 2017).

Concerns over financial implication may also impede successful archaeological research and conservation work. In the past, dispute has arisen between archaeologist, conservationist and consultant in conservation project due to consultant limiting the number of trenches on site due to additional cost that will be incurred and for fear of discovering more relics that will hamper the progress of the work. Thus, to avoid cases like this, it is helpful that the cost to conduct archaeological research in devised as a lump sum figure rather than itemised (Rahman, 2006).

\section{Professional Expert and Skilled Worker}

Presently, there is no body that oversee the practices of local archaeologists and the award of professional recognition or accreditation to the archaeologists. The number of archaeologist in Malaysia is rather small, and not all of them are involved in conservation archaeology of buildings, monuments and historical sites. Local archaeologists are involved in various archaeological fields such as prehistoric, proto-historic and historic. Therefore, unlike other professions, it is quite difficult to have a professional body that regulate and accredited the practice of archaeological research in conservation works in Malaysia. Therefore, rather than requiring local archaeologists to be 'professionally recognised', the authorities should look at their specialisation, education and experience in archaeological research when deciding on the eligibility of archaeologists to conduct archaeological research in conservation project. The quality of their previous research reports and having conducted studies that have led to practical conservation solutions could also be part of the eligibility criteria of archaeologists to conduct conservation archaeology projects (Muhamad, 2005; Roslan, Ramli, Shin, Choy, \& Razman, 2017).

The availability skilled workers is also paramount to ensure the success of archaeological research, and ultimately the conservation project. Conservation archaeological research requires several level of staff from the experts, and technical staff including field director, supervisors, photographers, clerks and general workers However, due to shortage of local skilled workers, it is common in the field that labourers, especially foreign, are employed to assist in archaeological research. These labourers are not experienced, much less skilled, workers. Strict supervisions must be enforced on work by these labourers, such as when digging, fearing some data may be destroyed. 
Asyaari Muhamad

The Importance of The Conservation/Preservation Works: A Challenge Towards the Future of National Heritage

\section{CONCLUSION AND RECOMMENDATION}

Conservation archaeological research field in the country is still new, and it needs a lot of reformations and improvements from all aspects. One such area is the eligibility and experience of archaeologists to conduct conservation archaeological research. The introduction of several initiatives like the ICOMS Charter and the National Heritage Act 2005 have helped to improve the credibility and importance of conservation archaeological research and archaeologists. Nevertheless, a clear guideline on archaeological research in conservation work must be prepared. The role played by archaeologists should be specified and respected. Several recommendations are listed here for implementation in order to fulfil the role of archaeologists and also for the interest of all other parties:

i. The National Heritage Department to set up a committee to discuss and prepare concept paper and guidelines on archaeological works regarding conservation of old buildings and historical sites.

ii. Archaeological research must be carried out first before conservation work takes place.

iii. Archaeological research team must be headed by an experienced archaeologist.

iv. Since archaeological research are carried out by experts, payment made must commensurate the fees paid to conservator or consultant.

v. Results from archaeological research must be evaluated by conservator and not by consultant before being implemented in conservation works.

vi. Significant discoveries such as artefact, structures and natural environment in historical sites or old building's yard should be evaluated for its significance in term of the building's history, local or national history. An exhibition space must be provided within the buildings so as to exhibit artefacts discovered. If remains of the building on structures that can be saved within a development area, it should be left in-situ as foundation museum and as the lowest floor for construction starting from second floor to the lowest floor. It can be the centre of attention to visitors who visit the building.

\section{REFERENCES}

Azman, N., Halim, S. A., Liu, O. P., \& Komoo, I. (2011). The Langkawi Global Geopark: Local community's perspectives on public education. International Journal of Heritage Studies, 17(3), 261-279.

Caple, C. (2000). Conservation skills: Judgement, method and decision making. London: Routledge.

Harun, N. Z. (2013). The challenges of historic public places in the development of historic urban areas. In W. W. Choong, A. H. Mohammed, \& M. T. S Mohammad (Eds), Non-structural environmental management (pp. 115-141). Johor Bahru: UTM Press. 
Harun, N. Z., Ariffin, N. A. M., \& Abdullah, F. (2017). Changes and threats in the preservation of the traditional Malay landscape. Planning Malaysia, 15(4), 6978.

Harun, S. N. (2004). Amalan kerja pemuliharaan bangunan bersejarah di Malaysia (Doctoral dissertation). Universiti Sains Malaysia, Malaysia.

Kassim, K. B. A. (2006, December). Konservasi pengenalan dan garis panduan terhadap kerja-kerja pemuliharaan warisan. Kursus Konservasi Monumen \& Tapak Tanah Bersejarah. December 16-18, 2006, Pulau Pinang, Malaysia.

Muhamad, A. (2005). Ekskavasi arkeologi Padang Pahlawan di Melaka: Menggali tamadun silam. MELAYU: Jurnal Antarabangsa Dunia Melayu, 4(2), 1-31

Muhamad, A. (2007). Kepentingan kajian arkeologi dalam kerja-kerja konservasi. Bengkel Konsevasi Kali Pertama. Melaka.

Rahman, N. H. S. N. A. (2006). Kepentingan arkeologi dalam kerja konservasi monumen dan tapak tanah bersejarah. Kursus Konservasi Monumen \& Tapak Tanah Bersejarah. December 16-18, 2006, Pulau Pinang, Malaysia.

Ramli, Z., Rahman, N. H. S. N. A., Ali, M. S. M., Wahab, M. R. A. \& Omar, M. A. (2016). Archaeological discoveries of 200BC coastal settlement in Pulau Kelumpang, Matang, Perak. Social Sciences (Pakistan). 11(13), 3264-3270.

Renfrew, C., \& Bahn, P. (1997). Archaeology: Theories, methods and practice. London: Thames and Hudson.

Roslan, Z., Ramli, Z., Shin, C., Choy, E. A., \& Razman, M. R. (2017). Local community perception on the importance of cultural-natural heritage protection and conservation: Case study in Jugra, Kuala Langat, Selangor, Malaysia. Journal of Food, Agriculture and Environment, 15(2), 107-110

Received: $1^{\text {st }}$ June 2018. Accepted: $1^{\text {st }}$ December 2018 